\title{
Diversity of nematodes on banana (Musa spp.) in Kenya linked to altitude and with a focus on the pathogenicity of Pratylenchus goodeyi
}

\author{
Douglas NyAnG'AU ${ }^{1,2, *}$, Janet ATANDI ${ }^{2, * *}$, Laura CORTADA ${ }^{2,3, * * *}$, Shem NCHORE ${ }^{1}$, \\ Maina MWANGI ${ }^{1, * * * *}$ and Danny COYNE ${ }^{2,3, * * * * *}$ \\ ${ }^{1}$ Kenyatta University, Department of Agricultural Science and Technology, P.O. Box 43844-00100, Nairobi, Kenya \\ ${ }^{2}$ International Institute of Tropical Agriculture (IITA East Africa), Icipe Campus, P.O. Box 30772-00100, Nairobi, Kenya \\ ${ }^{3}$ Nematology Research Unit, Department of Biology, Ghent University, Campus Ledeganck, Ledeganckstraat 35, B-9000
}

Ghent, Belgium

Received: 17 March 2021; revised: 28 May 2021

Accepted for publication: 29 May 2021

\begin{abstract}
Summary - Bananas (Musa spp.) are considered the most important fruit crop in Kenya, grown mostly by smallholder farmers. However, in the past two decades production has declined and has largely been attributed to plant pathogens, including plant-parasitic nematodes. To assess the understanding and awareness that banana farmers have of nematodes, a survey was conducted. The incidence, abundance and distribution of nematodes in relation to altitude were determined for different banana types on 180 farms and the pathogenicity of Pratylenchus goodeyi, originating from three different altitudinal locations, was compared on two banana cultivars. Just $2.3 \%$ of farmers were aware of nematode damage and symptoms, none of whom applied any management measures. The highest abundance of nematodes was recorded at an altitude range of 1601-2000 m a.s.1., with Pratylenchus, Meloidogyne and Helicotylenchus being the predominant genera. Across all altitudinal locations, cooking banana had higher densities of nematodes than dessert bananas. In pots, $P$. goodeyi populations from Embu (1300 m a.s.1.) appeared more aggressive and with higher levels of multiplication than the population from Oyugis (1100 m a.s.1.). Cooking banana ('Ng'ombe') was more susceptible than dessert banana ('Sukari Ndizi'). Nematode damage is more prominent in areas at higher altitude and on cooking banana cultivars. The findings provide key information in guiding informed and suitable management decision thresholds in relation to potential climate change.
\end{abstract}

Keywords - altitudinal gradient, climate adaptation, East African Highland banana, Helicotylenchus, Meloidogyne, nematode survey, smallholder farmers, yield loss.

In East and Central Africa, bananas (Musa spp.) are an immensely important staple food crop, fruit crop and source of income for millions of people. In Kenya, bananas are the most important fruit crop, accounting for $35.6 \%$ of the total fruit production, and represent the top fruit income earner (Kneoma, 2018). Bananas are often grown across a range of environments, providing a costeffective source of food energy year-round as well as an ideal infant food when other crops are off-season (Mbaka et al., 2008). Both dessert and cooking types are grown on an estimated 82000 ha with a total production of 1.43 million MT (Kneoma, 2018). The most important areas of production include Meru (14\%), Kirinyaga (12\%), Embu (10\%), Bungoma (8\%), Taita Taveta (7\%), Kisii (7\%) and Murang'a (6\%) (Ministry of Agriculture, Fisheries and Livestock, 2017). Production is mainly under smallholder conditions (Ng'ang'a et al., 2011).

The current rapid rate of population growth in Kenya, combined with evolving changes in food behaviour, provides an ideal opportunity for increasing banana produc-

\footnotetext{
* ORCID: https://orcid.org/0000-0002-0456-0174

** ORCID: https://orcid.org/0000-0003-3796-456X

*** ORCID: https://orcid.org/0000-0002-5953-3798

**** ORCID: https://orcid.org/0000-0003-4136-8963

***** Corresponding author, e-mail: d.coyne@cgiar.org
} 
tion in the country. Despite showing great production potential, however, banana yields have declined significantly over the past two decades (FAO, 2015). This reduction has been attributed to increased incidence of pests and diseases, including plant-parasitic nematodes (Reddy et al., 2007), worsened by a lack of effective control strategies (Inzaule et al., 2005).

Globally, nematodes are reported as major pests of banana (Coyne \& Kidane, 2018), causing yield losses of 30-60\% (Kamira et al., 2013; Sikora et al., 2018). This yield reduction is especially notable in Africa, where nematodes may cause up to 50\% loss in East African highland bananas ('EAHB') (Gaidashova et al., 2009; Coyne et al., 2018). In Kenya, a community of nematode species remains a threat to banana production, with Radopholus similis, Pratylenchus goodeyi and Helicotylenchus multicinctus reported as the main pathogenic nematodes affecting Musa spp. (Gichure \& Ondieki, 1977; Inzaule et al., 2005; Reddy et al., 2007; Waweru et al., 2014). When nematodes attack roots they create tissue damage, exposing the roots to secondary infections from fungal, bacterial and viral pathogens (Okafor et al., 2015; Smiley, 2015). Damaged roots are also less able to access adequate water and nutrients (Risède et al., 2010), suppressing plant growth, lengthening the fruiting period, reducing bunch weight and shortening the production life of mats (Wachira et al., 2013). Due to poor anchorage from damaged root systems, fruit-bearing plants may easily topple, especially during storms and strong winds (Coyne \& Kidane, 2018).

Crop productivity is heavily influenced by climate, which also strongly affects pest and disease infestation (Das et al., 2011). Historical records demonstrate an increase in global temperatures since the late 19th century (Kirtman et al., 2014) with Africa identified as probably the most vulnerable continent to climate change and climate variability (Niang et al., 2014). Consequently, changing climates will enable pests and diseases to colonise new localities and to survive outside their historic ranges (Harvell et al., 2002), including nematodes (Talwana et al., 2015; Erima et al., 2017).

Traditionally, some species of nematodes infecting banana have been distributed through a conspicuous temperature gradient, such as $R$. similis, which is traditionally found at lower altitudes with warmer temperatures (Blomme et al., 2012), while P. goodeyi traditionally occurs at higher altitudes where temperatures are cooler (Kashaija et al., 1994; Luambano et al., 2018). It is worth noting that these two species have different damage poten- tials as they present different levels of aggressiveness, with $R$. similis reported to be more damaging than $P$. goodeyi (Price, 2006; Plowright et al., 2013). Given that banana responds poorly to climate change, in relation to impacts on food and nutritional security assessments, the quantification of the climatic conditions for banana production is of particular importance to assess banana's climate sensitivity and, thereafter, to predict the potential impacts of climate change on banana production systems (Varma \& Bebber, 2019).

Owing to the shift in temperatures (King'uyu et al., 2000) along the altitudinal gradient linked to climate change in the East African Highlands, it is possible that the distribution of $R$. similis to higher altitudes, overlapping with $P$. goodeyi, will detrimentally impact 'EAHB' productivity (Coyne et al., 2018). To determine the incidence, abundance and distribution of nematodes at different altitudes on bananas in Kenya, both cooking and dessert type bananas were assessed for nematodes in key banana-growing localities. The differential pathogenicity of three populations of $P$. goodeyi recovered from three different altitudinal zones was also assessed.

\section{Materials and methods}

\section{FIELD SAMPLING IN MID (1100-1600 M A.S.L.) AND HIGH (1601-2000 M A.S.L.) ALTITUDE AREAS}

Banana farms from 12 major banana-producing areas of Kenya were sampled in Kisii (1100-1600 m a.s.l.), Migori (1100-1600 m a.s.1.), Homabay (1100-1600 m a.s.1.), Kakamega (1601-2000 m a.s.l.), Embu (1100-1600 m a.s.1.), Meru (1601-2000 m a.s.l.), Kiambu (1601-2000 m a.s.1.), Murang'a (1601-2000 m a.s.1.), Kirinyaga (1100$1600 \mathrm{~m}$ a.s.1.), Nyeri (1601-2000 m a.s.1.), Busia (1100$1600 \mathrm{~m}$ a.s.1.) and Bungoma (1601-2000 m a.s.l.) between November 2018 and July 2019 (Fig. 1). In each area, 15 distant farms were selected for sampling, resulting in a total of 180 sampled farms. In each farm, soil and roots were collected from two banana types: 'EAHB' (cooking type) and 'Cavendish' (dessert type), from a hole measuring $20 \times 20 \times 20 \mathrm{~cm}$ dug using a spade ca $1 \mathrm{~m}$ from the banana plant/mat. Five functional roots measuring $\mathrm{ca} 10 \mathrm{~cm}$ each were also sliced longitudinally to assess percentage root damage using the Root Necrosis Index (RNI) according to Speijer \& De Waele (1997) and Coyne et al. (2014). The geographical coordinates and altitude were recorded for each farm. 


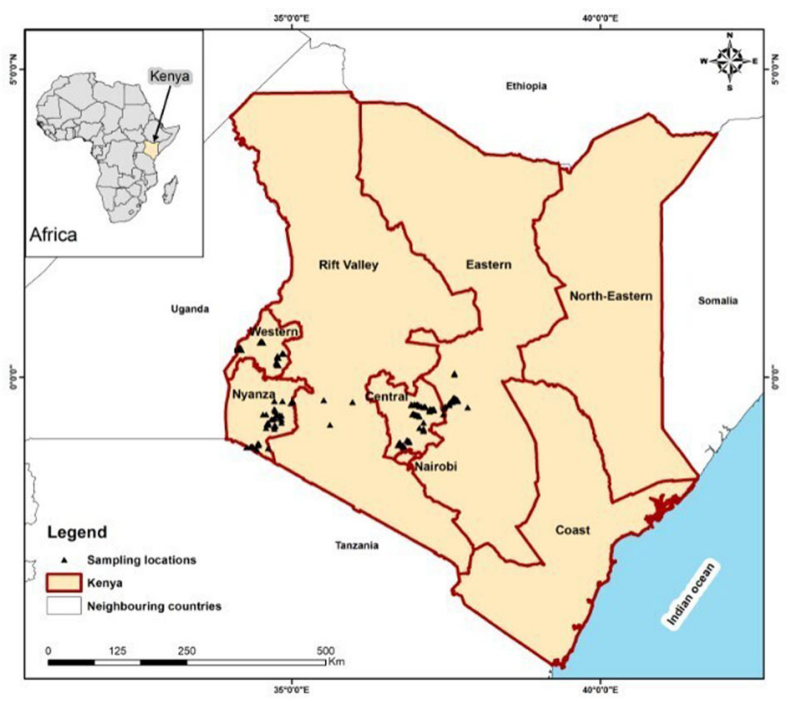

Fig. 1. Map of Kenya showing the sampling locations ( $\mathbf{\Delta})$.

\section{AWARENESS OF PLANT-PARASITIC NEMATODES ON BANANAS AND NEMATODE EVALUATION}

The study assessed farmers' knowledge levels and perceptions of nematodes as pests affecting banana production. This was executed through a structured questionnaire with each of the 180 selected farmers.

\section{EXTRACTION AND PROCESSING OF PLANT-PARASITIC NEMATODES}

In the laboratory, banana roots were washed, blotted dry on tissue paper, then chopped to $c a 1 \mathrm{~cm}$ length pieces. Nematodes were extracted from $5 \mathrm{~g}$ roots and $100 \mathrm{~cm}^{3}$ of soil for $48 \mathrm{~h}$, using the modified Baermann technique (Coyne et al., 2014). Nematodes were counted and examined under a Leica MZ12 dissecting microscope with under-stage lighting at $\times 20$ magnification. Nematodes were killed using the hot water bath method at $65^{\circ} \mathrm{C}$ (Roy et al., 2014) and fixed in 4\% formalin (Coyne et al., 2014) to facilitate identification. Nematodes were identified to genus level using a Leica 2500 compound microscope at $40 \times$ magnification, based on morphological features described by Hooper et al. (2005). Photos were captured at $40 \times$ magnification.

\section{PATHOGENICITY POT TRIAL ASSESSMENT}

The reproductive potential and pathogenicity of three populations of $P$. goodeyi were assessed in pots on two banana cultivars (dessert type 'Sukari Ndizi' and cooking type 'Ng'ombe') at two locations, the International
Centre for Insect Physiology and Ecology (icipe), Nairobi (1600 m a.s.1.), and at an identified farm in Kisii (1300 m a.s.1.). Three populations of $P$. goodeyi were recovered from separate locations at different altitudes: Oyugis (1100 m a.s.1.), Embu (1300) and Nairobi (1600). Banana tissue culture plantlets were obtained from Jomo Kenyatta University of Agriculture and Technology at the hardening stage and transplanted into 1.51 plastic pots filled with steam-sterilised loamy textured soil. Plants were inoculated with 2000 nematodes (pot) ${ }^{-1}$ using infected banana root tissue segments containing predominantly $P$. goodeyi. Roots were bulk harvested from a farm from each of the three locations where high densities of mainly $P$. goodeyi were observed. Nematode densities were calculated as above and root weights equating to 2000 P. goodeyi used to inoculate each pot. The root segments were split longitudinally, cut to $c a 1 \mathrm{~cm}$ length and mixed homogenously. The cut root segments were applied within a $3 \mathrm{~cm}$ radius furrow around the plant and covered with soil. A non-inoculated control using autoclaved banana root segments was included and treatments were replicated ten times in a completely randomised design. The banana plantlets were maintained under shade and irrigated twice weekly. The experiments were terminated at 120 days post-inoculation. At harvest, root fresh weight and shoot fresh weight were recorded; RNI and nematode densities in the soil and roots were assessed and the nematode reproductive factor (RF) calculated:

$$
\mathrm{RF}=(\text { Final population/Initial population })
$$

\section{DATA ANALYSIS}

Data from questionnaires were coded and analysed using Statistical Package for Social Sciences (SPSS) version 16.0. The nematode count data were transformed by $\log _{10}(x+1)$ to reduce the coefficient of variation. Percentage RNI from the survey and pot trials were transformed by arcsine $(\sqrt{ } \mathrm{x})$ to ensure that data conformed to normal distribution. All data were subjected to analysis of variance (ANOVA) using $\mathrm{R}$ version 3.5.1 ( $\mathrm{R}$ Core Team, 2015) system statistical software and means separated by Tukey's multiple comparison test of significance at $(P \leqslant 0.05)$. Correlation between $P$. goodeyi densities in banana roots and root damage was computed using the Spearman's rank correlation coefficient. Descriptive statistics were used to summarise data. 
Table 1. Plant-parasitic nematodes recovered from banana farms at different altitude ranges in Kenya.

\begin{tabular}{|c|c|c|c|c|}
\hline Order & Sub-order & Family & Genus & Altitudinal range ${ }^{1}$ \\
\hline \multirow[t]{12}{*}{ Tylenchida } & \multirow[t]{12}{*}{ Tylenchina } & \multirow[t]{2}{*}{ Pratylenchidae } & Pratylenchus & Mid, High* \\
\hline & & & Radopholus & Mid \\
\hline & & \multirow[t]{4}{*}{ Hoplolaimidae } & Hoplolaimus & Mid, High \\
\hline & & & Rotylenchus & Mid \\
\hline & & & Helicotylenchus & Mid*, High \\
\hline & & & Scutellonema & Mid, high \\
\hline & & Aphelenchoididae & Aphelenchoides & Mid, High \\
\hline & & Aphelenchidae & Aphelenchus & Mid \\
\hline & & Meloidogynidae & Meloidogyne & Mid* $^{*}$, High \\
\hline & & \multirow{2}{*}{ Tylenchulidae } & Tylenchus & Mid, High \\
\hline & & & Filenchus & Mid, High \\
\hline & & Tylenchorhynchidae & Tylenchorhynchus & Mid \\
\hline Dorylaimida & Dorylaimina & Longidoridae & Longidorus & Mid \\
\hline Triplonchida & Diphtherophorina & Trichodoridae & Trichodorus & Mid \\
\hline
\end{tabular}

${ }^{1}$ Mid altitude $=1100-1600 \mathrm{~m}$ a.s.1., high altitude $=1601-2000 \mathrm{~m}$ a.s.l. An asterisk indicates that genus occurrence was significantly greater in the altitudinal range.

\section{Results}

\section{AWARENESS BY FARMERS OF PLANT-PARASITIC NEMATODES ON BANANAS}

The majority of the farmers growing bananas (97.8\%) did not know that nematodes are pests of bananas, with just $2.2 \%$ of farmers being aware. None of the interviewed farmers was aware that their banana fields were infested and damaged by nematodes, even though some (2\%) were familiar with bananas toppling over but were unaware of the cause. The majority (98\%) of farmers had not noticed bananas toppling in their farms.

\section{EFFECT OF ALTITUDE AND BANANA TYPE ON ROOT DAMAGE}

Root necrosis was greater $(P<0.05)$ at higher altitudes $(14.9 \%)$, in comparison to the mid altitudes $(8.5 \%)$, although there were no differences $(P>0.05)$ between 'EAHB' (12.5\%) and 'Cavendish' (11.0\%).

\section{OCCURRENCE OF PLANT-PARASITIC NEMATODE GENERA}

Fourteen nematode genera belonging to eight families in the orders Tylenchida, Dorylaimida and Triplonchida were found associated with banana (Table 1). Pratylenchus goodeyi was the most commonly recovered (66.1\%) species followed by H. multicinctus (16.3\%) and
Meloidogyne spp. (8.9\%), while $R$. similis (0.3\%) was rarely observed (Table 2). These nematodes were recovered from both soil and roots across altitudinal ranges and in both 'EAHB' and 'Cavendish' bananas (Figs 2, 3). On the effect of altitude on plant-parasitic nematode density, cooking banana showed greater densities $(P<0.05)$ of $P$. goodeyi isolated from high altitude banana-producing areas than from mid altitudes (Fig. 2). Helicotylenchus multicinctus was recorded in greater $(P<0.05)$ densities in mid altitude than in higher altitudes, while Meloidogyne spp. were recovered in greater $(P<0.05)$ densities from mid altitudes in comparison to high altitude areas (Fig. 2). Radopholus similis was barely detectable in mid altitudes and it was not recovered from high altitude areas. On 'Cavendish', $P$. goodeyi densities were similar $(P>0.05)$ in both high and mid altitude areas (Fig. 3) and H. multicinctus was recorded in greater densities $(P<0.05)$ in mid altitude than in the high altitude areas (Fig. 3). Meloidogyne spp. densities were greater $(P<0.05)$ in mid altitude in comparison to high altitude areas, whilst $R$. similis registered extremely low densities in mid altitudes and was absent at high altitude banana-growing areas (Fig. 3).

\section{DISTRIBUTION OF PLANT-PARASITIC NEMATODES ACROSS BANANA PRODUCTION AREAS IN KENYA}

Greater densities $(P<0.05)$ of nematodes were associated with banana in Kakamega, a high altitude banana production area (>1600 $\mathrm{m}$ a.s.l.), than other areas. In Kakamega, greater nematode densities were associated 
Table 2. Mean density and percentage incidence of nematode species/genera recovered from banana production areas in Kenya.

\begin{tabular}{|c|c|c|}
\hline Nematode & $\begin{array}{l}\text { Mean density } \\
(5 \mathrm{~g} \text { root })^{-1}\end{array}$ & $\begin{array}{l}\text { Percentage } \\
\text { incidence }\end{array}$ \\
\hline Pratylenchus goodeyi & $105 \pm 56.67$ & 66.1 \\
\hline $\begin{array}{c}\text { Helicotylenchus } \\
\text { multicinctus }\end{array}$ & $26 \pm 18.91$ & 16.3 \\
\hline Meloidogyne spp. & $14 \pm 12.31$ & 8.9 \\
\hline Hoplolaimus spp. & $4 \pm 3.01$ & 2.6 \\
\hline Filenchus spp. & $4 \pm 2.71$ & 2.3 \\
\hline Longidorus spp. & $2 \pm 1.61$ & 1.3 \\
\hline Trichodorus spp. & $2 \pm 0.87$ & 0.9 \\
\hline Aphelenchoides spp. & $1 \pm 0.54$ & 0.4 \\
\hline Rotylenchus spp. & $0.49 \pm 0.21$ & 0.3 \\
\hline Radopholus similis & $0.40 \pm 0.18$ & 0.3 \\
\hline Tylenchus spp. & $0.33 \pm 0.06$ & 0.1 \\
\hline Aphelenchus spp. & $0.31 \pm 0.07$ & 0.1 \\
\hline Tylenchorhynchus spp. & $0.27 \pm 0.02$ & 0.1 \\
\hline
\end{tabular}

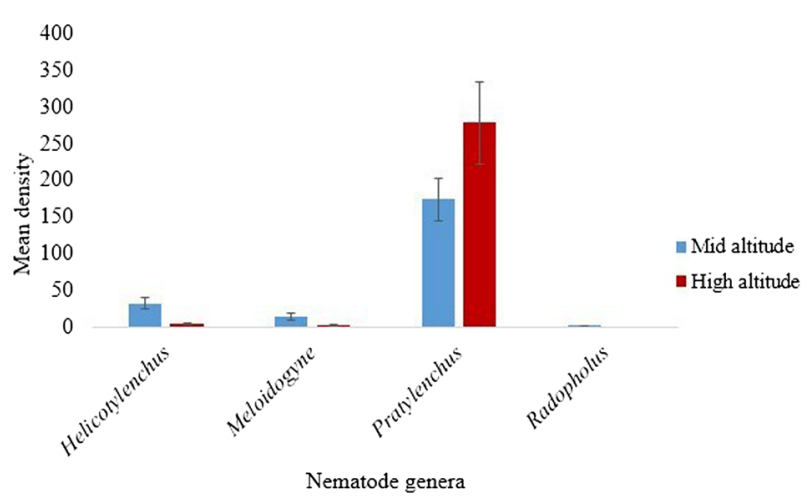

Fig. 2. Mean densities (5 $\mathrm{g}$ fresh root $)^{-1}$ of plant-parasitic nematode genera associated with East African Highland cooking banana 'EAHB' in mid and high altitude banana production areas in Kenya.

with 'EAHB' than 'Cavendish' (Fig. 4), as was the case in Embu, Meru and Kisii (Fig. 5). The opposite was observed in Bungoma and Homabay, where 'Cavendish' supported greater nematode densities than 'EAHB'.

\section{EFFECT OF BANANA TYPE ON PLANT-PARASITIC NEMATODE DENSITY}

'EAHB' supported higher $(P<0.05)$ densities of $P$. goodeyi than 'Cavendish' at both the high and mid altitude ranges, whilst there was no significant difference between banana types for $H$. multicinctus or Meloidogyne spp. (Fig. 6) in high altitude ranges. However, H. multicinctus

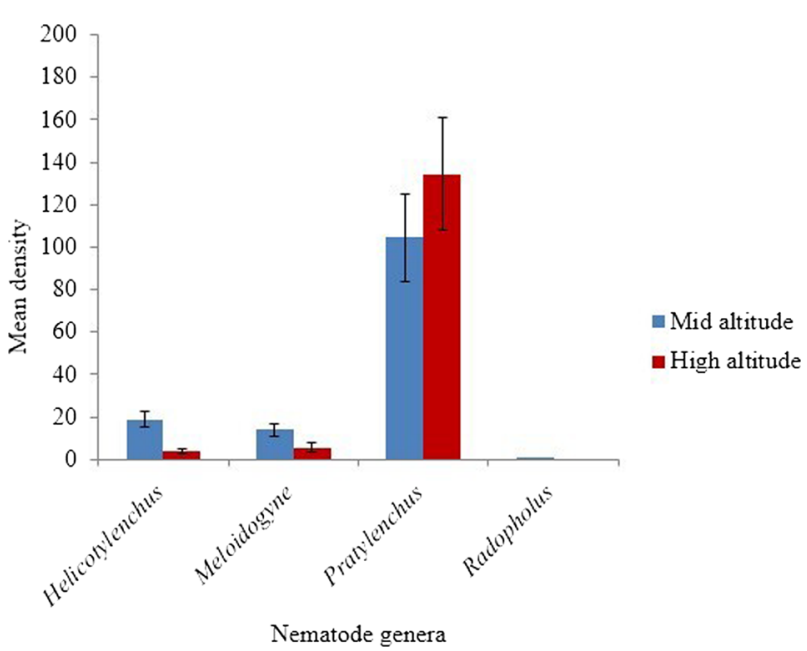

Fig. 3. Mean densities ( $5 \mathrm{~g}$ fresh root $)^{-1}$ of plant-parasitic nematode genera associated with dessert bananas ('Cavendish') in mid and high altitude banana production areas in Kenya.

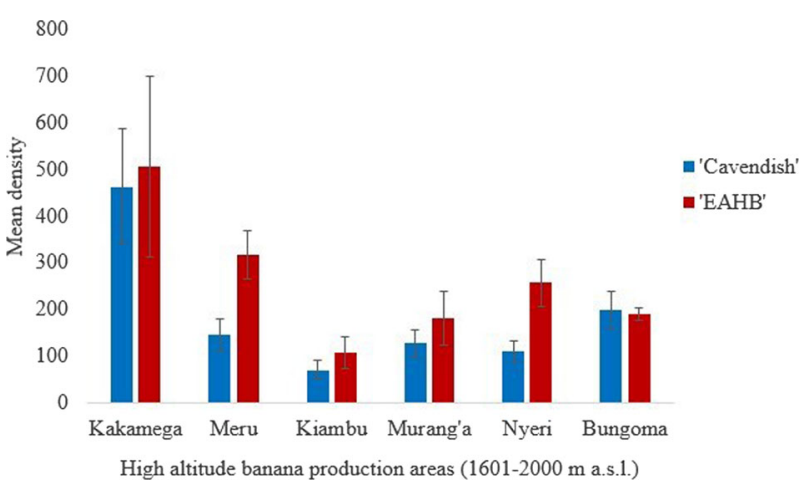

Fig. 4. Mean densities ( $5 \mathrm{~g}$ fresh root $)^{-1}$ of plant-parasitic nematodes from dessert ('Cavendish') and East African Highland cooking banana ('EAHB') roots at high altitude $(1601-2000 \mathrm{~m}$ a.s.l.) banana production areas in Kenya.

was recovered in greater $(P<0.05)$ densities on 'EAHB' than 'Cavendish' at the mid altitude ranges, whilst $R$. similis was not recovered from banana at the high altitude ranges (> $1600 \mathrm{~m}$ a.s.1.) on either 'Cavendish' or 'EAHB', and were negligible in mid altitudes (Fig. 7).

\section{EFFECT OF PRATYLENCHUS GOODEYI POPULATIONS ON BANANA ROOT DAMAGE}

The percentage root necrosis following inoculation with the three populations of $P$. goodeyi did not differ $(P>0.05)$ between the two study sites at Nairobi and Kisii (Table 3) or between banana type $(P>$ 0.05). However, root necrosis caused by the three $P$. goodeyi populations varied and was significantly $(P=$ 


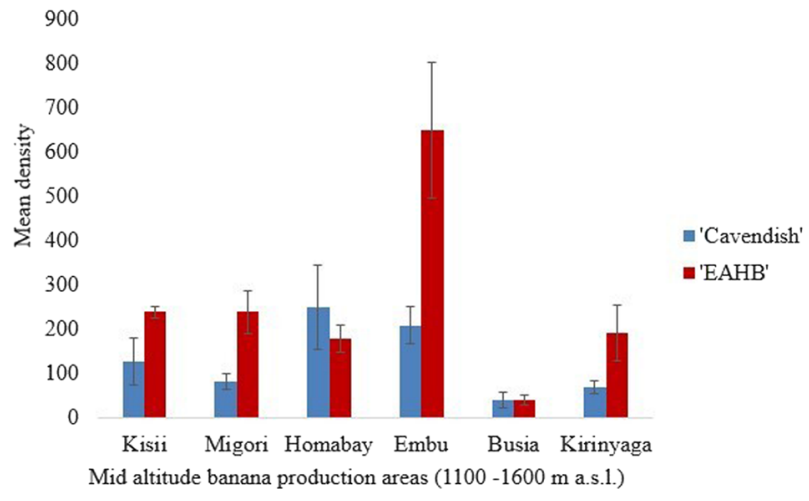

Fig. 5. Mean densities ( $5 \mathrm{~g}$ fresh root $)^{-1}$ of plant-parasitic nematodes from dessert ('Cavendish') and East African Highland cooking banana ('EAHB') roots at mid altitude (1100-1600 m a.s.l.) banana production areas in Kenya.

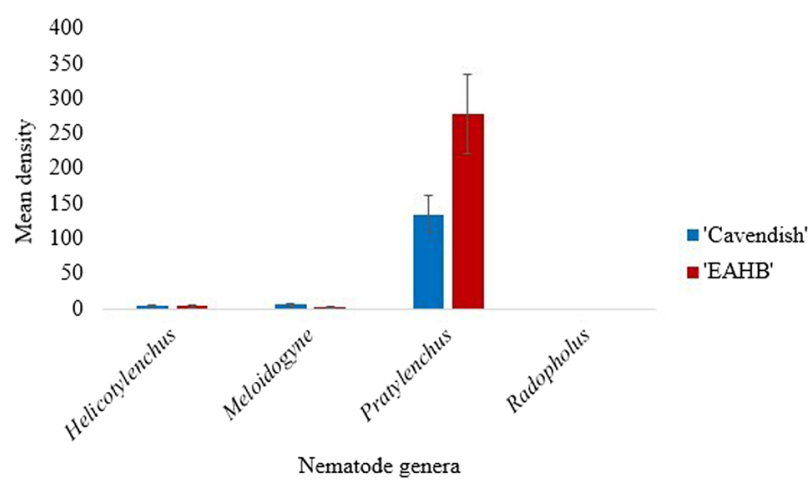

Fig. 6. Mean densities ( $5 \mathrm{~g}$ fresh root $)^{-1}$ of plant-parasitic nematodes from dessert ('Cavendish') and East African Highland cooking banana ('EAHB') roots at high altitude regions in Kenya (1601-2000 m a.s.1.).

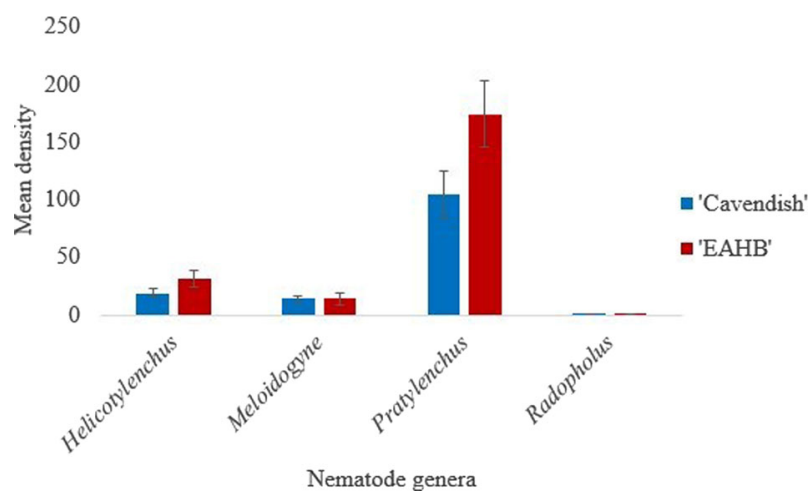

Fig. 7. Mean densities ( $5 \mathrm{~g}$ fresh root $)^{-1}$ of plant-parasitic nematodes from dessert ('Cavendish') and East African Highland cooking banana ('EAHB') roots at mid altitude regions in Kenya (1100-1600 $\mathrm{m}$ a.s.1.).
Table 3. Effect of Pratylenchus goodeyi populations on cooking ('Ng'ombe') and dessert banana ('Sukari Ndizi') genotypes at two trial sites in Kenya.

\begin{tabular}{lccc}
\hline & $\begin{array}{c}\text { Mean percentage } \\
\text { necrosis }\end{array}$ & $t$ value & $P$ value \\
\hline Trial site & & & \\
$\quad$ Kisii & $5.8 \pm 9.01$ & 1.25 & 0.218 \\
$\quad$ Nairobi & $8.5 \pm 11.93$ & & \\
Banana genotype & & & \\
$\quad$ 'Ng'ombe' & $6.9 \pm 5.12$ & 0.25 & 0.817 \\
$\quad$ 'Sukari Ndizi' & $7.4 \pm 8.75$ & & \\
Population & & $F$-value & \\
$\quad$ Embu & $8.3 \pm 11.60$ & 9.86 & 0.273 \\
$\quad$ Nairobi & $15.1 \pm 14.08$ & & \\
$\quad$ Oyugis & $4.7 \pm 10.62$ & & \\
\hline
\end{tabular}

Non-inoculated control had no nematodes and differed significantly $(P<0.05)$ from three $P$. goodeyi populations.

0.003) greater for the Nairobi population than the Oyugis population with a difference of $10.4 \%$ (Table 4 ). The severity of root necrosis was not significantly different between the Nairobi and Embu populations, or between the Oyugis and Embu populations (Table 4).

\section{EFFECT OF BANANA CULTIVAR AND TRIAL SITE ON PRATYLENCHUS GOODEYI POPULATION DENSITY}

Across the two trial sites, the mean density of $P$. goodeyi was $346(5 \mathrm{~g} \mathrm{root})^{-1}$ for Nairobi and 266 $(5 \mathrm{~g} \text { root })^{-1}$ for Kisii, although there was no significant difference $(P=0.479)$ (Table 5$)$. The mean $P$. goodeyi density on 'Ng'ombe' was significantly $(P=0.002)$ greater compared with 'Sukari Ndizi' but did not differ among the three populations $(P>0.05)$ (Table 5). A post ANOVA test showed variations in mean densities of $P$. goodeyi across the three populations, although these variations were not significant $(P>0.05)$ (Table 6).

\section{REPRODUCTIVE FACTOR OF THREE PRATYLENCHUS GOODEYI POPULATIONS ACROSS TWO TRIAL SITES}

From the two trial sites, the RF was similar for the three $P$. goodeyi populations in Kisii, compared with Nairobi $(P>0.05)$ (Table 7). However, the RF differed significantly between banana cultivars, with 'Ng'ombe' recording a greater $(P<0.0048) \mathrm{RF}$ compared to 'Cavendish' (Table 7), but with no differences between $P$. goodeyi populations $(P=0.1728)$ (Table 7). 
Table 4. Post analysis of variance test results of banana root necrosis damage by Pratylenchus goodeyi populations originating from three altitudinal locations in Kenya.

\begin{tabular}{lccccc}
\hline Population & Contrast difference & SE & $t$ & $P>t$ & $95 \%$ Confidence interval \\
\hline NRB $v$ s EMB & 6.87 & 2.78 & 2.47 & 0.069 & -0.3614 .10 \\
OYG $v$ s EMB & 3.55 & 2.86 & 1.24 & 0.600 & -10.993 .88 \\
OYG $v$ s NRB & 10.43 & 2.92 & 3.56 & 0.003 & -18.032 .83 \\
\hline
\end{tabular}

$\mathrm{EMB}=\mathrm{Embu} ; \mathrm{NRB}=$ Nairobi; OYG = Oyugis; $\mathrm{SE}=$ standard error. Non-inoculated control had no nematodes and differed significantly $(P<0.05)$ from three $P$. goodeyi populations.

Table 5. Density of Pratylenchus goodeyi populations originating from three altitudinal locations on cooking ('Ng'ombe') and dessert banana ('Sukari Ndizi') genotypes.

\begin{tabular}{lccc}
\hline & Mean & $t$ value & $P$ value \\
\hline Trial site & & & \\
$\quad$ Kisii & $266 \pm 78.28$ & -0.7 & 0.479 \\
$\quad$ Nairobi & $346 \pm 63.01$ & & \\
Banana genotype & & & \\
$\quad$ Ng'ombe' & $487 \pm 62.65$ & -3.25 & 0.002 \\
$\quad$ 'Sukari Ndizi' & $134 \pm 20.03$ & & \\
Population & & $F$-value & \\
$\quad$ Embu & $557 \pm 49.81$ & 4.76 & 0.671 \\
$\quad$ Nairobi & $271 \pm 51.79$ & & \\
$\quad$ Oyugis & $376 \pm 39.97$ & & \\
\hline
\end{tabular}

Non-inoculated control had no nematodes and differed significantly $(P<0.05)$ from three $P$. goodeyi populations.

\section{CORRELATION BETWEEN PRATYLENCHUS GOODEYI DENSITIES IN BANANA ROOTS AND ROOT DAMAGE}

A positive $(r=0.177)$ and significant $(P<0.05)$ correlation was observed between nematode density in the root system and root necrosis.

\section{Discussion}

The current study shows clearly that $P$. goodeyi is the most prominent nematode at higher altitude areas ( $>1600 \mathrm{~m}$ a.s.l.) of Kenya, compared to its occurrence in mid altitude areas $(<1600 \mathrm{~m}$ a.s.l.), reflecting previous studies from across the region (Kashaija et al., 1994; Gaidashova et al., 2004; Reddy et al., 2007; Kamira et al., 2013). However, recent findings by Luambano et al. (2017) show that both $P$. goodeyi and $P$. coffeae occur at lower altitudes, such as on the islands of Zanzibar and across the Tanzanian coast. Luambano et al. (2018) further reported $P$. coffeae on banana in mainland Tanzania, where the nematode had previously not been reported.
Therefore, Pratylenchus species, and in particular P. goodeyi (Mgonja et al., 2019), appear to be shifting from their 'known' distribution in East Africa to outside their traditional ranges. Previous studies have demonstrated an altitudinal demarcation for $P$. goodeyi distribution (Talwana et al., 2003; Gaidashova et al., 2009; Kamira et al., 2013), while the current study shows $P$. goodeyi occurring at lower altitudes in the mid altitude belt. Pratylenchus goodeyi was seldom observed in low altitudinal elevations in East Africa until recently when the nematode was encountered in Tanzania (Luambano et al., 2017), raising questions as to whether variations in ecotypes, which are more tolerant of higher temperatures, are developing (Coyne, 2009). Although $P$. goodeyi infection can affect banana root efficiency (Wang et al., 2009) and expose plants to secondary infections (Tanimola et al., 2013; Smiley, 2015) at high altitudes, it is yet to be determined how this impacts bananas at higher temperatures in lower altitudes.

From the current study, $H$. multicinctus was recovered from elevations above $1600 \mathrm{~m}$ a.s.l., unlike earlier reports (Kashaija et al., 1994; Gaidashova et al., 2004) where the nematode was observed in all sites below $1600 \mathrm{~m}$ a.s.l. but not above. This could relate to the mixed banana production systems observed in most of the farms surveyed. Helicotylenchus multicinctus is recognised as a key nematode constraint to Musa production, especially plantain in West Africa (Coyne, 2009) but also on 'EAHB' (Hartman et al., 2010). Comparatively, H. multicinctus is not viewed as being as aggressive as $R$. similis, but where it occurs in high populations it can cause severe root damage (Tanimola et al., 2013).

Meloidogyne spp. was widely distributed in both mid and high altitude areas $(<1600 \mathrm{~m}$ a.s.l.) in low densities. Although Meloidogyne spp. have been similarly encountered in mid altitude areas in the region (Kamira et al., 2013), the nematodes have not regularly been encountered at high altitudes but are more prevalent at lower altitudes (<1400 m a.s.l.) (Kashaija et al., 1994; Talwana et al., 2003; Reddy et al., 2007). Whilst studies have shown that 
Table 6. Post analysis of variance test results for Pratylenchus goodeyi densities of populations originating from three altitudinal locations.

\begin{tabular}{lccrrr}
\hline Population & Contrast difference & SE & $t$ value & $P>t$ & $95 \%$ Confidence interval \\
\hline NRB $v$ s EMB & -285.66 & 149.56 & -1.91 & 0.228 & -674.06102 .73 \\
OYG vs EMB & -180.50 & 153.85 & -1.17 & 0.645 & -580.05219 .03 \\
OYG $v$ s NRB & 105.15 & 157.27 & 0.67 & 0.909 & -303.28513 .59 \\
\hline
\end{tabular}

$\mathrm{EMB}=\mathrm{Embu} ; \mathrm{NRB}=$ Nairobi; OYG = Oyugis; $\mathrm{SE}=$ standard error. Non-inoculated control had no nematodes and differed significantly $(P<0.05)$ from three $P$. goodeyi populations

Table 7. Reproductive factor (RF) of three Pratylenchus goodeyi populations originating from three altitudinal locations on cooking ('Ng'ombe') and dessert banana ('Sukari Ndizi') genotypes at two trial sites in Kenya.

\begin{tabular}{lcccc}
\hline & Mean RF & SE & $t$ value & $P$ value \\
\hline Trial site & & & & \\
Kisii & 0.23 & 0.05 & 0.95 & 0.3455 \\
Nairobi & 0.35 & 0.11 & & \\
Banana genotype & & & & \\
'Ng'ombe' & 0.46 & 0.12 & 2.87 & 0.0048 \\
'Sukari Ndizi' & 0.12 & 0.02 & & \\
Population & & & $F$-value & \\
Embu & 0.45 & 0.16 & 1.78 & 0.1728 \\
Nairobi & 0.19 & 0.03 & & \\
Oyugis & 0.23 & 0.06 & & \\
\hline
\end{tabular}

$\mathrm{SE}=$ standard error.

Meloidogyne spp. can affect bunch weight (Van den Bergh et al., 2000) and cause root galling (Coyne et al., 2014), Meloidogyne spp. are generally not considered a major pest of bananas in East Africa (Tanimola et al., 2013).

Interestingly, $R$. similis, a damaging species and prevalent elsewhere in the region, was rarely detected in the current study, further supporting observations by Reddy et al. (2007) who observed it infrequently. This observation could be ascribed to the increasing use and popularity of tissue culture plants in Kenya, which would limit the spread of $R$. similis as the distribution of this species results mainly from the dissemination of infected banana planting materials (Price, 2006; Blomme et al., 2012). Radopholus similis has also traditionally been found at altitudes below $1400 \mathrm{~m}$ a.s.l. (Kashaija et al., 1994; Gaidashova et al., 2004; Reddy et al., 2007) where temperatures are higher, although in the current study the nematode was detected only infrequently across all survey sites.

The current study identified more species of nematodes on cooking banana than on dessert bananas, with high densities of the dominant $P$. goodeyi observed on 'EAHB' compared to 'Cavendish', confirming earlier findings (Reddy et al., 2007), where more lesion nematodes were observed on 'EAHB' in most Kenyan districts surveyed. This observation could be explained in part by the endemic and dominant cultivation of 'EAHB' in the cooler highlands (Karamura et al., 1998), as opposed to lowland areas (Gaidashova et al., 2004).

In the pathogenicity study of $P$. goodeyi populations, the higher densities of $P$. goodeyi from the Nairobi trial (1600 m a.s.l.), compared to that of Kisii (1300 m a.s.l.), could be due in part to the existence of an inherent degree of variability in aggression and infectivity between temperatures and within the pathogen biology (Talwana et al., 2003). This current observation of $P$. goodeyi at altitudes of $1300 \mathrm{~m}$ a.s.l. indicates that the temperature range of the nematode is shifting, as it is now occurring in areas at lower altitudes where it has previously not been reported (Luambano et al., 2017; Mgonja et al., 2019), challenging observations that the nematode is confined to higher altitudinal ranges above $1500 \mathrm{~m}$ a.s.l. (Kamira et al., 2013). The higher root necrosis observed in Nairobi compared with Kisii may be related to the higher average altitude of Nairobi ( $>1600 \mathrm{~m}$ a.s.l.) compared to Kisii $(<1300 \mathrm{~m}$ a.s.l.). Greater nematode densities and RF was recorded from ' $\mathrm{Ng}$ 'ombe' but, interestingly, with lower root damage, while 'Sukali Ndizi' had lower nematode densities and RF but greater root damage. Although root damage varied across sites on both cultivars, 'Sukali Ndizi' would appear to be less tolerant of $P$. goodeyi than 'Ng'ombe'. These observations reflect the views of Marin et al. (2009) that reproductive fitness of the nematode and the amount of root damage caused on the host may not always be related, suggesting that these attributes could be under the control of different genes (Shaner et al., 1992). In the current study, it was noted that a demonstrable degree of variability in nematode aggressiveness exists and that infection levels vary between temperatures within sites and among the three $P$. goodeyi populations. This 
damage could be influenced by factors such as plant cultivar or climate (Gauggel et al., 2005), confirming reports by Talwana et al. (2003). The future of banana production in the region, therefore, would benefit from the long-term development of management thresholds to cope with these changing threats.

The variability of root necrosis among the three P. goodeyi populations observed across sites mirrors those found by Speijer \& De Waele (1997) and Nega \& Fetena (2015), who observed that overall nematode damage levels displayed large variability among different sites in Uganda and Ethiopia. This observation suggests that in rolling out breeding programmes for nematode resistance, banana cultivars that maintain a strong root system when infected with high nematode densities provide a good source of nematode management (Barekye et al., 2000). Comparatively, the Embu population isolated from a temperature of $20^{\circ} \mathrm{C}$ had a significantly greater RF than the Nairobi $\left(24^{\circ} \mathrm{C}\right)$ or Oyugis $\left(26^{\circ} \mathrm{C}\right)$ populations. While these observations typify the multiplication indices of plant-parasitic nematodes at higher temperatures (Talwana et al., 2003; Coyne et al., 2014; Wu et al., 2014), they contradict the thermophobic character of $P$. goodeyi. Further, the results from the current study indicate that $P$. goodeyi is adapted to a wide range of temperatures despite showing thermal sensitivity in aggressiveness. The current findings indicate that $P$. goodeyi is spreading geographically, regardless of climatic conditions or altitudinal elevation (Coyne et al., 2018; Mgonja et al., 2020).

The current study has demonstrated that the vast majority of banana growers in Kenya are not aware of nematodes as pests infecting their bananas. These findings confirm other studies (Brooks, 2004; Wang \& Hooks, 2009; Chitamba et al., 2016), where most growers are unaware of nematodes as a major cause of Musa production problems and have only limited knowledge of banana nematodes as a pest. In addressing the nematode challenge, therefore, there is a need to raise farmers' awareness and promote the use of healthy, nematode-free planting materials (Coyne, 2009).

\section{Acknowledgements}

The authors gratefully acknowledge the financial support from the donors who supported this work through their contributions to the CGIAR Fund (https://www. cgiar.org/funders/) and in particular to the CGIAR Research Program for Roots, Tubers and Bananas (CRP-
RTB), and also the 'GCE Phase II: Neuropeptide Nematicides' project opportunity ID: OPP1130274, led by Queens University, Belfast, and by the European Union project: Microbial Uptakes for Sustainable management of major banana pests and diseases, Grant Agreement 727624 .

\section{References}

Araya, M., De Waele, D. \& Vargas, R. (2002). Occurrence and population densities of nematode parasites of banana (Musa AAA) roots in Costa Rica. Nematropica 32, 21-33.

Barekye, A., Kashaija, I.N., Tushemereirwe, W.K. \& Adipala, E. (2000). Comparison of damage levels caused by Radopholus similis and Helicotylenchus multicinctus on bananas in Uganda. Annals of Applied Biology 137, 273-278. DOI: 10. 1111/j.1744-7348.2000.tb00068.x

Blomme, G., Ploetz, R., Jones, D., De Langhe, E., Price, N., Gold, C., Geering, A., Viljoen, A., Karamura, D., Pillay, M. et al. (2012). A historical overview of the appearance and spread of Musa pests and pathogens on the African continent: highlighting the importance of clean Musa planting materials and quarantine measures. Annals of Applied Biology 162, 426. DOI: 10.1111/AAB. 12002

Brooks, F.E. (2004). Plant-parasitic nematodes of banana in American Samoa. Nematropica 34, 65-72.

Chitamba, J., Manjeru, P., Mudada, N., Chinheya, C.C. \& Handiseni, M. (2016). Current banana smallholder farmers' farming practices and knowledge on plant-parasitic nematodes associated with banana (Musa spp.) in Rusitu Valley, Zimbabwe. African Journal of Agricultural Research 11, 11201125. DOI: 10.5897/AJAR2015.10638

Coyne, D. (2009). Pre-empting plant-parasitic nematode losses on banana in Africa: which species do we target?. Acta Horticulturae 828, 227-235. DOI: 10.17660/ActaHortic.2009. 828.23

Coyne, D.L. \& Kidane, S. (2018). Nematode pathogens. In: Jones, D. (Ed.). Handbook of diseases of banana, abacá and enset, 2nd edition. Wallingford, UK, CAB International, pp. 429-461.

Coyne, D.L., Nicol, J.M. \& Claudius-Cole, B. (2014). Practical plant nematology: a field and laboratory guide, 2nd edition. Cotonou, Benin, SP-IPM Secretariat, IITA.

Coyne, D.L., Cortada, L., Dalzell, J.J., Claudius-Cole, A.O., Haukeland, S., Luambano, N. \& Talwana, H. (2018). Plantparasitic nematodes and food security in sub-Saharan Africa. Annual Review of Phytopathology 56, 381-403. DOI: 10. 1146/annurev-phyto-080417-045833

Das, D.K., Singh, J. \& Vennila, S. (2011). Emerging crop pest scenario under the impact of climate change - a brief review. Journal of Agriculture Physiology 11, 13-20.

Erima, R., Kubiriba, J., Komutunga, E., Nowakunda, K., Namanya, P., Seruga, R., Nabulya, G., Ahumuza, E. \& Tushe- 
mereirwe, W.K. (2017). Banana pests and diseases spread to higher altitudes due to increasing temperature over the last 20 years. African Journal of Environmental Science and Technology 11, 601-608. DOI: 10.5897/AJEST2016.2173

FAO (2015). The World Banana Forum (WBF): Working together for sustainable banana production and trade. Introductory note. Available online at www.fao.org/economic/ worldbananaforum (accessed 27 October 2016).

Gaidashova, S.V., Okech, S., Van den Berg, E., Marais, M., Gatarayiha, C.M. \& Ragama, P.E. (2004). Plant-parasitic nematodes in banana-based farming systems in Rwanda: species profile, distribution and abundance. African Plant Protection 10, 27-33.

Gaidashova, S.V., van Asten, P., De Waele, D. \& Delvaux, B. (2009). Relationship between soil properties, crop management, plant growth and vigour, nematode occurrence and root damage in east African highland banana cropping systems: a case study in Rwanda. Nematology 11, 883-894. DOI: 10. 1163/156854109X430310

Gauggel, C.A., Sierra, F. \& Arévalo, G. (2005). The problem of banana root deterioration and its impact on production: Latin America's experience. In: Turner, D.W. \& Rosales, F.E. (Eds). Banana root system: towards a better understanding for its productive management. Proceedings of an international symposium held in San José, Costa Rica, 3-5 November 2003. Montpellier, France, INIBAP, pp. 13-22.

Gichure, E. \& Ondieki, J.J. (1977). A survey of banana nematodes in Kenya. Journal of Plant Diseases and Protection 84, 724-728.

Hartman, J.B., Vuylsteke, D., Speijer, P.R., Ssango, F., Coyne, D.L. \& De Waele, D. (2010). Measurement of the field response of Musa genotypes to Radopholus similis and Helicotylenchus multicinctus and the implications for nematode resistance breeding. Euphytica 172, 139-148. DOI: 10.1007/ s10681-009-0104-4

Harvell, C.D., Mitchell, C.E., Ward, J.R., Altizer, S., Dobson, A.P., Ostfeld, R.S. \& Samuel, M.D. (2002). Climate warming and disease risks for terrestrial and marine biota. Science 296, 2158-2162.

Hooper, D.J., Hallmann, J. \& Subbotin, S.A. (2005). Methods for extraction, processing and detection of plant and soil nematodes. In: Luc, M., Sikora, R.A. \& Bridge, J. (Eds). Plant parasitic nematodes in subtropical and tropical agriculture, 2nd edition. Wallingford, UK, CAB International, pp. 53-86.

Inzaule, S.S.S., Kimani, F., Mwatuni, S. \& Makokha, M. (2005). Status of banana pests and diseases in western Kenya. African Crop Science Proceedings 7, 309-312.

Kamira, M., Hauser, S., van Asten, P., Coyne, D. \& Talwana, H.L. (2013). Plant parasitic nematodes of banana and plantain in eastern and western Democratic Republic of Congo. Nematropica 43, 216-225. DOI: 10.13140/2.1.3970.4969

Karamura, E., Frison, E., Karamura, D.A. \& Sharrock, S. (1998). Banana production systems in eastern and southern Africa. In:
Picq, E., Fouré, E. \& Frison, E.A. (Eds). Bananas and food security. Montpellier, France, INIBAP, pp. 401-412.

Kashaija, I.N., Speijer, P.R., Gold, C.S. \& Gowen, S.R. (1994). Occurrence, distribution and abundance of plant parasitic nematodes of banana in Uganda. African Crop Science Journal 2, 99-104.

King'uyu, S.M., Ogallo, L.A. \& Anyamba, E.K. (2000). Recent trends of minimum and maximum surface temperatures over eastern Africa. Journal of Climate 13, 2876-2886.

Kirtman, S.B., Power, S.B., Adedoyin, J.A., Boer, G.J., Bojariu, R., Camilloni, I., Doblas-Reyes, F.J., Fiore, A.M., Kimoto, M. \& Meehl, G.A. (2014). Near-term climate change: projections and predictability. In: Stocker, T.F., Qin, D., Plattner, G.K., Tignor, M., Allen, S.K. \& Boschung, J. (Eds). Climate change 2013: the physical science basis. Contribution of working group, the fifth assessment report of the intergovernmental panel on climate change. Cambridge, UK, Cambridge University Press, pp. 953-1028. DOI: 10.1017/ CBO9781107415324.023

Kneoma (2018). https://knoema.com/atlas/Kenya/topics/ Agriculture/Crops-Production-Quantity-tonnes/Bananasproduction. Accessed: 1 May 2020.

Luambano, N.D., Masunga, M., Kashando, B., Mziray, M. \& Mgonja, D. (2017). Distribution of plant parasitic nematodes associated with banana crops in Tanzania. In: Proceedings of the 21st symposium of the Nematological Society of Southern Africa (NSSA), Fairmont Zimbali Resort, South Africa 7-11 May 2017. [Abstr.]

Luambano, N.D., Kashando, B.E., Masunga, M.M., Mwenisongole, A.E., Mziray, M.F., Mbaga, J.E., Polini, R.M. \& Mgonja, D.M. (2018). Status of Pratylenchus coffeae in banana-growing areas of Tanzania. Physiological and Molecular Plant Pathology 105, 102-109. DOI: 10.1016/J. PMPP.2018.08.002

Marin, D.H., Barker, K.R., Kaplan, D.T., Sutton, T.B. \& Opperman, C.H. (1999). Aggressiveness and damage potential of central American and Caribbean populations of Radopholus spp. in banana. Journal of Nematology 31, 377-385.

Mbaka, J.N., Mwangi, M. \& Mwangi, M.N. (2008). Banana farming as a business: the role of tissue cultured planting materials in Kenya. Journal of Applied Biosciences 9, 354361 .

Mgonja, D.M., Temu, G.E., Mziray, M.F., Kashando, B.E., Mwenisongole, A.E., Masunga, M.M., Lyantagaye, S.L. \& Luambano, N.D. (2019). Morphological and molecular identification of Pratylenchus goodeyi associated with banana in Tanzania. Tanzania Journal of Science 45, 265-278.

Mgonja, D.M., Temu, G.E., Lyantagaye, S.L., Makaranga, A., Ndunguru, J.C. \& Luambano, N.D. (2020). Plant parasitic nematodes occurrence and genetic diversity of banana cultivars grown in Tanzania. Plant Omics Journal 13, 21-29. DOI: 10.21475/POJ.13.01.20.p2085

Ministry of Agriculture, Fisheries and Livestock (2017). Horticulture validated report 2016-2017. Available online 
at http://kilimodata.developlocal.org/dataset/horticulturevalidated-report-2016-2017/resource/c7758a80-9102-481ea6c2-fa983081221d. (Accessed May 2017).

Nega, G. \& Fetena, S. (2015). Root necrosis assessment of plant parasitic nematodes of banana (Musa spp.) at Arbaminch, Ethiopia. Journal of Biology, Agriculture and Healthcare 5, 76-80.

Ng'ang'a, M.P., Kahangi, E.M., Onguso, J.M., Losenge, T. \& Mwaura, P. (2011). Analyses of extra-cellular enzymes production by endophytic fungi isolated from bananas in Kenya. African Journal of Horticulture Science 5, 1-8.

Niang, I., Ruppel, O.C., Abdrabo, M.A., Ama, E., Lennard, C., Padgham, J., Adelekan, I.O., Archibald, S., Balinga, A., Barkhordarian, A. et al. (2014). Africa. In: Barros, V.R., Field, C.B., Dokken, D.J., Mastrandrea, M.D., Mach, K.J., Bilir, T.E., Chatterjee, M., Ebi, K.L., Estrada, Y.O. \& Genova, R.C. et al. (Eds). Climate change 2014 impacts, adaptation and vulnerability. Part B: regional aspects. Contribution of working group II to the fifth assessment report of the intergovernmental panel on climate change. Cambridge, UK, Cambridge University Press, pp. 1199-1265.

Okafor, O.E., Ugwuoke, K.I., Mba, C.L., Okafor, F.C. \& Mbadianya, J.I. (2015). The distribution of plant-parasitic nematodes of Musa spp. in Nsukka Agricultural Ecological zone, Enugu State, Nigeria. African Journal of Agricultural research 10(48), 4338-4347. DOI: 10.5897/AJAR2014.9159

Plowright, R., Speijer, P., Dusabe, J. \& Coyne, D. (2013). Analysis of the pathogenic variability and genetic diversity of the plant-parasitic nematode Radopholus similis on bananas. Nematology 15, 41-56. DOI: 10.1163/156854112x643914

Price, N. (2006). The banana burrowing nematode, Radopholus similis (Cobb) Thorne, in the Lake Victoria region of east Africa: its introduction, spread and impact. Nematology 8, 801-817. DOI: $10.1163 / 156854106779799240$

$\mathrm{R}$ Core Team (2015). $R$ : a language and environment for statistical computing. Vienna, Austria, R Foundation for Statistical Computing. Available online at https://www.Rproject.org. (accessed 1 February 2016).

Reddy, K.V.S., Prasad, J.S., Speijer, P.R., Sikora, R.A. \& Coyne, D.L. (2007). Distribution of plant parasitic nematodes on Musa in Kenya. InfoMusa 16, 18-23.

Risède, J.R., Chabrier, C., Dorel, M., Dambas, T., Achard, R. \& Quénéhervé, P. (2010). Integrated management of banana nematodes: lessons from a case study in the French West Indies. Banana case study - guide number 4. Montpellier, France, CIRAD.

Roy, K., Roy, S., Sarkar, S., Rathod, A. \& Pramanik, A. (2014). Diversity of migratory nematode endoparasites of banana. Journal of Crop and Weed 10, 375-391. DOI: 10.13140/RG. 2.2.28604.08323

Shaner, G., Stromberg, E.L., Lacy, G.H., Barker, K.R. \& Pirone, T.P. (1992). Nomenclature and concepts of pathogenicity and virulence. Annual Review of Phytopathology 30, 47-66. DOI: 10.1146/annurev.py.30.090192.000403
Sikora, R.A., Coyne, D.L., Hallman, J. \& Timper, P. (Eds) (2018). Plant parasitic nematodes in subtropical and tropical agriculture, 3rd edition. Wallingford, UK, CAB International.

Smiley, R.W. (2015). Root-lesion nematodes: biology and management in Pacific northwest wheat cropping systems. PNW Extension Bulletin 617. Corvallis, OR, USA, Oregon State University.

Speijer, P.R. \& De Waele, D. (1997). Screening of Musa germplasm for resistance and tolerance to nematodes. INIBAP Technical Guidelines 1. Montpellier, France, INIBAP.

Talwana, H., Sibanda, Z., Wanjohi, W., Kimenju, W., Luambano-Nyoni, N., Massawe, C., Manzanilla-López, R.H., Davies, K.G., Hunt, D.J., Sikora, R.A. et al. (2015). Agricultural nematology in east and southern Africa: problems, management strategies and stakeholder linkages. Pest Management Science 72, 226-245. DOI: 10.1002/ps.4104

Talwana, H.A.L., Speijer, P.R., Gold, C.S., Swennen, R.L. \& De Waele, D. (2003). A comparison of the effects of the nematodes Radopholus similis and Pratylenchus goodeyi on growth, root health and yield of an east African highland cooking banana (Musa AAA-group). International Journal of Pest Management 49, 199-204. DOI: 10.1080/ 0967087031000085033

Tanimola, A.A., Asimeaa, A.O. \& Ofuru-Joseph, S. (2013). Status of plant-parasitic nematodes on plantain (Musa parasidiaca (L.)) in Choba, Rivers State, Nigeria. World Journal of Agricultural Sciences 9, 189-195.

Van den Bergh, I., Tam, V.T. \& Chau, N.N. (2000). Assessment of the occurrence and damage potential of nematodes on bananas in north and central Vietnam. In: Nhi, H.H., Molina, A., Van den Bergh, I. \& Sen, P.T. (Eds). Highlights of Musa research and development in Vietnam. Hanoi, Vietnam, VASI, pp. 134-149.

Varma, V. \& Bebber, D.P. (2019). Climate change impacts on banana yields around the world. Nature Climate Change 9, 752-757. DOI: 10.1038/S41558-019-0559-9

Wachira, P.M., Kimenju, J.W., Kiarie, J.W., Kihurani, A.W. \& Mwaniki, S.W. (2013). Occurrence and diversity of nematode destroying fungi in banana production zones in Maragua, Kenya. Journal of Agricultural Science 5, 180-186. DOI: 10. 5539/JAS.V5N12P180

Wang, K. \& Hooks, C.R.R. (2009). Plant-parasitic nematodes and their associated natural enemies within banana (Musa spp.) plantings in Hawaii. Nematropica 39, 57-73.

Waweru, B., Turoop, L., Kahangi, E., Coyne, D. \& Dubois, T. (2014). Non-pathogenic Fusarium oxysporum endophytes provide field control of nematodes, improving yield of banana (Musa spp.). Biological Control 74, 82-88. DOI: 10.1016/J. BIOCONTROL.2014.04.002

Wu, H.Y., He, Q., Liu, J., Luo, J. \& Peng, D.L. (2014). Occurrence and development of the cereal cyst nematode (Heterodera avenae) in Shandong, China. Plant Disease 98, 1654-1660. DOI: 10.1094/PDIS-08-13-0830-RE 